\title{
MONOCLONAL ANTIBODIES TO IDENTIFY TOMATO MOSAIC TOBAMOVIRUS (TOMV)
}

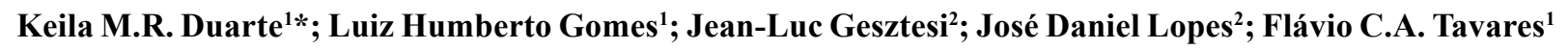 \\ ${ }^{1}$ Departamento de Genética, Escola Superior de Agricultura "Luiz de Queiroz", Universidade de São Paulo, Piracicaba, SP, \\ Brasil. ${ }^{2}$ Departamento de Microbiologia, Parasitologia e Imunologia, Universidade Federal de São Paulo, São Paulo, SP, Brasil \\ Submitted: February 09, 1999; Returned to authors for corrections: November 10, 2000; Approved: June 28, 2001
}

\begin{abstract}
Monoclonal antibodies were obtained against Tomato mosaic tobamovirus (ToMV) isolated in Brazil. One antibody (8G7G2) isotyped as IgG2b ( $\kappa$ light chain) showed strong specificity and very low cross reaction with the Tobacco mosaic virus (TMV). It can be used in identification of tomato mosaic virus (ToMV).
\end{abstract}

Key words: Tomato mosaic tobamovirus, ELISA, monoclonal antibodies

\section{INTRODUCTION}

The mosaic of tomato crops can be caused by a specific virus species classified in the Tobamovirus genus (14). The infected tomato plants show light and dark green mottled areas on the leaves and the fruits may be reduced in size and number with uneven ripening (12). The disease can be disseminated through infected tools and seeds, which control can be more difficult. It is very important in Europe and already do occur in Brazil $(1,5)$. Three Tomato mosaic tobamovirus strains (ToMV) were reported and one have spread out in São Paulo plantations (1), where $30 \%$ of the tomato Brazilian production is harvested (6).

The precise identification of ToMV is done by timeconsuming differentiation by host plant tests and polyclonal antibody serology, which presents cross-reaction with tobacco mosaic tobamovirus (TMV), which also infects tomato plants. This could be avoided by using highly specific and uniform monoclonal antibodies (MAb) suitable for plant virus diagnosis $(5,8,13)$. This work tested this approach aiming practical uses in selecting monoclonal antibodies to recognize specific ToMV epitopes.

\section{MATERIALS AND METHODS}

Samples of ToMV and TMV were CsCl-gradient purified according to Caner et al. (2). To produce monoclonal antibodies, six-week-old BALB/c female mice were immunized by one subcutaneous injection of $20 \mu \mathrm{g}$ of purified ToMV in Freund's Complete Adjuvant, followed by new injections of PBS $(8 \mathrm{~g} \mathrm{NaCl}$; $0.2 \mathrm{~g} \mathrm{KCl} ; 1.5 \mathrm{~g} \mathrm{Na}_{2} \mathrm{HPO}_{4}$ and $0.2 \mathrm{~g} \mathrm{KH}_{2} \mathrm{PO}_{4}$ ) every 15 days (7). High antibody titers were obtained after five to six immunizations, and one final injection was done intravenously two days prior to cell fusion. Mice blood samples for titration were taken through the ocular plexus before every injection, centrifuged and the serum stored at $-20^{\circ} \mathrm{C}$. Plate trapped antigen enzyme immunoassay/PTA-ELISA was used for antisera titration and positive colony screening (3). Wells of 96-well microtiter plates were coated with $50 \mu \mathrm{l}$ of antigen solution containing $1 \mu \mathrm{g} / \mathrm{ml}$ purified ToMV after incubation at $37^{\circ} \mathrm{C}$ for one hour. Both ToMV and TMV were used in titration of sera culture supernatants. The conjugate was horseradish peroxidase/ortho phenylene diamine dye (OPD) enzyme system in phosphate/citrate buffer. Absorbance measurements were taken after 3-4 minutes at 492 nm (ELISA Reader BioRad, model 550).

The higher antibody titer mouse had the spleen cells fused to the myeloma cell mouse line SP2/Ag14 (7,13). After fusion, cells were distributed over ten 96-well microtiter plates macrophage feeder layered and incubated in $5 \% \mathrm{CO}_{2}$ atmosphere at $37^{\circ} \mathrm{C}$ (water jacked chamber, Forma Scientic, model 3158). The feeder layer was harvested from mouse peritoneal macrophage cells in RPMI-1640 medium (Gibco-BRL, 31800-022) and transferred to $\mathrm{CO}_{2}$ incubator chamber $37^{\circ} \mathrm{C}$ for 48 hours. Ten

\footnotetext{
* Corresponding author. Mailing address: Departamento de Genética, Escola Superior de Agricultura "Luiz de Queiroz" (ESALQ), Universidade de São Paulo (USP), Caixa Postal 83. 13418-900, Piracicaba, SP, Brasil. E-mail: kmrduart@cena.usp.br
} 
days after cell fusion $50 \mu \mathrm{l}$ of supernatant fluid were taken from the wells for PTA-ELISA assay (3). High titer colonies were expanded over ten 96-well microplates with macrophages feeder layer and indirect ELISA was performed for colony selection. After ten days of growth, ten colonies were cloned and again screened by an indirect ELISA (4). The selected MAbs were isotyped for IgG1, IgG2a, IgG2b, IgM, IgA, Kappa and Lambda patterns $(2,4,7)$ using a mouse immunoglobulin monoclonal antibody-based isotyping kit system (Gibco-BRL, cat. no. 9660SA). Microplates coated with ToMV were treated with the MAbs ascite obtained $(4,15)$ and purified in sepharose-protein A column of class $\mathrm{G}$ specific rabbit polyclonal antibodies (BioRad, cat. no. 153-6153). Purification methods were specific for each immunoglobulin class (14). The procedure is described in the ELISA protocol (3).

\section{RESULTS AND DISCUSSION}

According to the methodology for MAbs production against ToMV, six-week-old BALB/c female mice were immunized and the one presenting high antibody OD titer units was sacrificed. Spleen cells from this mouse were fused to the myeloma cell mouse line SP2/Ag14 (7,13). Fused colony cell growth was observed in 452 out of 960 wells of microtiter plates, from which twenty three colonies were selected after ELISA tests $(3,4)$. Four monoclonal antibodies against ToMV with very low cross-reactivity with TMV were selected. TMV is a tobamovirus with very closely related characteristics, including morphology, symptoms in host plants and polyclonal antibodies based ELISA titer $(14,16)$. The titers of 8G7G2, 10H9F9, 8C2F12 and $8 \mathrm{C} 12 \mathrm{H} 12 \mathrm{MAbs}$ are presented in Fig. 1.

The efficiency of MAbs production was quite low and only four interesting MAbs were obtained. Examples like this have been observed elsewhere for quite similar epitopes under scrutiny as observed for detection and characterization of PPV (10) and for WSSMV viruses (9). Where monoclonal antibodies cross-reactivity is detected Western Blot analysis is used as done before to distinguish among prunus virus isolates (PVIS) from plum pox potyvirus (PPV) (10).

The isotype test experiments $(2,3,4,7,15)$ indicated that $8 \mathrm{G} 7 \mathrm{G} 2$ $\mathrm{MAb}$ belongs to IgG2b kappa chain immunoglobulin. The specificity, as estimated from competition assays against ToMV, has shown to be about $20 \%$ higher for $80 \mathrm{ug}$ and $160 \mathrm{ug}$ ascite concentrations (Fig. 2). Therefore some epitopes can also be shared by rabbit anti-serum against ToMV indicating that they are quite reactive. The results also indicate that $10 \mathrm{H} 9 \mathrm{~F} 9,8 \mathrm{C} 2 \mathrm{~F} 12$ and $8 \mathrm{C} 12 \mathrm{H} 12$ antibodies can still be of polyclonal nature although being very specific to ToMV. They should require additional cloning and selection for possible monoclonal production.

Similar isotyping kit results were obtained testing MAbs anti potato S-virus and potato M-virus (11) and wheat yellow mosaic virus (WYMV), where about $80 \%$ of the MAbs belong

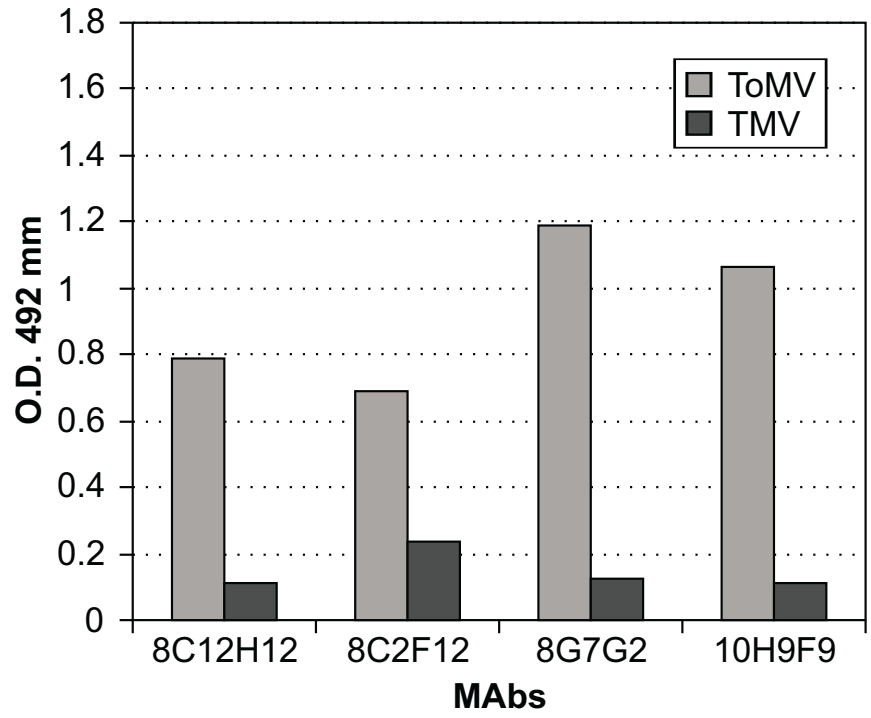

Figure 1. ToMV monoclonal antibodies titers, detected by PTAELISA, using microplates coated with $1 \mu \mathrm{g} / \mathrm{ml}$ of ToMV and TMV (O.D. measurements).

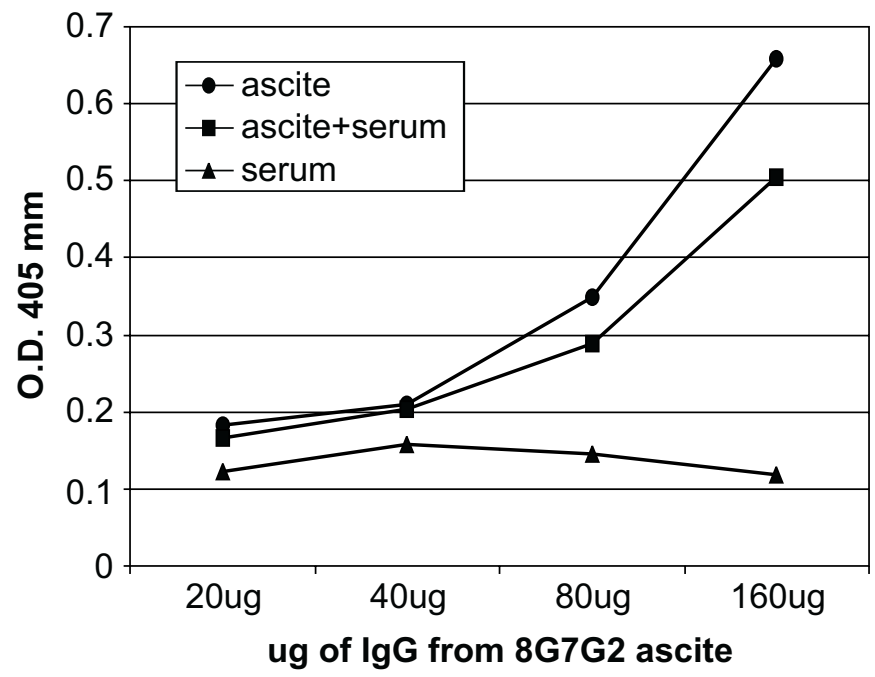

Figure 2. Competition assay using $8 \mathrm{G} 7 \mathrm{G} 2$ ascites purified in sepharose-protein A and rabbit anti-serum against ToMV (O.D. measurements).

to IgG sub-classes. They are the best ones as field test for identification of different strains, with the frequency of about $70 \%$ of the total IgG cells decreasing cross-reaction with other compounds (9). In conclusion, 8G7G2 monoclonal antibody gives the highest reaction among the four MAbs selected and is undoubtedly able to recognize ToMV with high specificity. This effective MAb against ToMV has an application in field tests aiming future use in virus-free tomato seeds certification. 


\section{ACKNOWLEDGMENTS}

The suggestions of Marcelo A. Pavan, Sergio Echeverrigaray and Cristiana Argueso are kindy appreciated. This work was carried out with financial support of CAPES and FAPESP.

\section{RESUMO}

\section{Anticorpos monoclonais para identificar o tobamovírus do mosaico do tomateiro (ToMV)}

Foram obtidos anticorpos monoclonais contra o vírus do mosaico do tomateiro (ToMV) isolado no Brasil. O anticorpo 8G7G2 isotipado como IgG2b (cadeia leve $\kappa$ apresentou alta especificidade para o ToMV e baixa reação cruzada com o vírus do mosaico do tabaco (TMV) e poderá ser usado na identificação do ToMV.

Palavras-chave: vírus do mosaico do tomateiro, ELISA, anticorpos monoclonais

\section{REFERENCES}

1. Bastos, H.B. Vírus do mosaico do tomateiro: Levantamento, identificação, caracterização de estirpes em algums regiões do Estado de São Paulo e determinação da herança da resistência. Botucatu, 1998. 58p. (M.Sc. - Dissertation - Faculdade de Ciências Agronômicas, UNESP).

2. Caner, J.; Colariccio, A.; Chagas, C.M.; Alba, A.P.C.; Vicente, M. Identificação de um isolado do vírus do mosaico do tomateiro (ToMV) no estado de São Paulo. Fitopatol. Bras., 15:347-350, 1990.

3. Crowther, J.R. ELISA: theory and practice. 1995. (Methods in molecular biology, 42)
4. Duarte, K.M.R. Anticorpos monoclonais e policlonais para identificação do tobamovírus do mosaico do tomateiro (ToMV) em plantas de tomate (Lycopersicon esculentum Mill.). Piracicaba, 2000. 87p. (Ph.D Thesis. Escola Superior de Agricultura "Luiz de Queiroz" - USP).

5. Fernandes, J.J.; Carvalho, M.G.; Almeida, E.G. Distribuição do Mosaico em tomatais de duas regiões produtoras de Minas Gerais. Fitopatol. Bras., 8:625, 1983.

6. FNP Consultoria e Comércio. Agrianual 99, São Paulo, 2000. p.516.

7. Gesztesi, J.; Puccia, R.; Travassos, L.R.; Vicentini, A.P.; Moraes, J.Z. de; Franco, M.F.; Lopes, J.D. Monoclonal antibodies against the 43,000 Da glycoprotein from Paracoccidioides brasiliensis modulate laminin-mediated fungal adhesion to epithelial cells and pathogenesis. Hybridoma, 15:415-22, 1996.

8. Halk, E.L.; de Boer, S. Monoclonal antibodies in plant-disease research. Ann. Rev. Phytopathol., 23:321-350, 1985.

9. Hariri, D.; Delaunay, T.; Gomes, L.; Filleur, S.; Plovie, C.; Lapierre, $\mathrm{H}$. Comparison and differentiation of wheat yellow mosaic virus (WYMV), wheat spindle streak mosaic virus (WSSMV) and barley yellow mosaic virus (BaYMV) isolates using WYMV monoclonal antibodies. European J. Plant Pathol., 102:283-292, 1996.

10. James, D.; Godkin, S.E.; Eastwell, K.C.; MacKenzie, D.J. Identification and differentiation of prunus virus isolates that cross-react with plum pox virus and apple stem pitting antisera. Plant Dis., 80:536543, 1996.

11. JärVekulg, L.; Sõber, J.; Sinjärv, R.; Toots, I.; Saarma, M. Timeresolved fluoroimmunoassay of potato virus $\mathrm{M}$ with monoclonal antibody. Ann. Appl. Biol., 114:279-291, 1989.

12. Jones, J.B.; Stall, R.E.; Zitter, T.A. Compendium of tomato diseases, St. Paul, APS Press, 1991, 75p.

13. Köhler, G.; Milstein, C. Continuous cultures of fused cells secreting antibody of pre-defined specificity. Nature, 256:495-497, 1975.

14. Murphy, F.A.; Fauquet, C.M.; Bishop, D.H.L.; Ghabrial, S.A.; Jarvis A.W.; Martelli, G.P.; Mayo, M.A.; Summers, M.D. Virus Taxonomy. Sixth Report of the International Commitee on Taxonomy of Viruses. Arch. Virol., Suppl. 10, 1995. 586p.

15. Oi, V.T.; Herzenberg, L.A. Antibody purification: protein A-sepharose column chromatography. In: Mishell, B.B.; Shiigi, S.M. Selected methods in celular immunology. Freeman, 1980, p.368-370.

16. Van Regenmortel, M.H.V.; Burckard, J. Detection of a wide spectrum of tobacco mosaic virus strains by indirect enzyme-linked immunosorbent assays (ELISA). Virology, 106:327-334, 1980. 